\title{
Reform Method and Effect Analysis of University Library Education Based on Digital Information Technology
}

\author{
Huimin Zhang $^{1}$ \\ Handan University
}

\begin{abstract}
The traditional way of library education has not been adapted to the educational requirements in the information age, so it is urgent to reform the education of university libraries. This article selects the statistical survey method to carry on the system analysis on the present situation, functional evolution process, and existing issues of Chinese library education; puts forward the reform strategy and function realization way of university library education based on digital information technology; through the statistics of the number of on-line and off-line college students visiting in a university library, this article analyzes the application effect of library education based on digital information technology. The research of this article has important guiding significance for improving the information level of university library education and guiding the reform of university library education
\end{abstract}

\section{Keywords}

Digital Information Technology $\bullet$ Library Education $・$ Reform Method $\bullet$ Application Effect

*Research Project of Social Science Development in Hebei Province in 2018"Reading Promotion of Children in Public Libraries from the Perspective of Graded Reading"(No.:201803120513)

${ }^{1}$ Correspondence to: Huimin Zhang (MA), Handan University, Handan 056005, China. Email: beautifulworldice@ 163.com

Citation: Zhang, H.M. (2018). Reform Method and Effect Analysis of University Library, Education Based on Digital Information Technology. Educational Sciences: Theory \& Practice, 18(5), 2540-2546.

http://dx.doi.org/10.12738/estp.2018.5.156 
At present, the information level of university libraries in China is not high, and the traditional library education mode still plays a dominant role in most colleges and universities. University library education is the extension and supplement of college classroom education, and it plays an important role in the knowledge supplement of college students (Zhou, Liu \& Li, 2011). With the application of computer network information technology in university libraries, the information reform of university libraries will play a more and more important role in guiding the prosperity and development of higher education in China.

The research on the information development of university libraries in China has already achieved results: some scholars put forward that libraries are the heart of the education information in colleges and universities; some scholars think that the change of traditional ideas of teachers and students is the key to the reform of library education informatization function; still some scholars advocate that library education should constantly update the concept of service to provide students with an all-round knowledge service system (Hou et al., 2014). The rich research conclusions have laid a foundation for the research of this article, but there are some shortcomings in the former researches, such as the incomplete reform method and the lack of practical application effect analysis, which is the focus of this research.

The main analysis method adopted in this article is statistical survey method, which realizes a comprehensive analysis of the educational reform methods of university libraries in China, and summarizes the main reform strategies by qualitative means. In this article, the effect of library information reform is analyzed quantitatively with examples.

\section{Function Evolution of University Libraries under the Background of Digital Information Technology}

\section{Definition, evolution and present situation of university library function}

Digital information technology has been widely used in college education, and provides assistance to college education in many ways such as multimedia classroom, distance education, E-learning, computer-aided teaching, intelligent learning terminal, and mobile learning and sharing terminal. With the development of information and socialization in colleges and universities, libraries rely on rich collection resources, information resources and network technology in the form of information network centre in colleges and universities, and directly or indirectly participates in teaching (Gan et al., 2012).

Intelligent definition of university libraries. The dissemination and development of library knowledge is the main function of university library education. The functions of the library integrate the dissemination of knowledge, the cultivation of ability and the promotion of students' comprehensive literacy. Its functions are divided into traditional educational functions and educational functions in the information age. The traditional educational function is to receive knowledge and culture in a unified and passive way with people gather at certain time and place. In the information age, the function of education is to use the network actively to receive all kinds of education in the libraries under the network environment (Korobkov, 2004). 
Library function evolution. The library function evolution can be divided into three stages as shown in Table 1.

It can be seen from the table that the function of libraries changes obviously from ancient times to contemporary times and then to modern times. Modern libraries have been endowed with more functions, and need to play a more important role in educational communication and knowledge communication (Fahmy, 2014).

Present situation of university library education. At the present stage, university library education in China mainly functions: 1 . entrance training of freshmen, 2. teaching of literature retrieval course, 3. lectures and training, 4. information literacy education, 5. library information education, 6. network training course, 7. teachers and librarians training and other aspects. Through the statistics of library education in 100 domestic universities, we can get the distribution of current education in university libraries as shown in Figure 1.

Table 1

Function of the Libraries

\begin{tabular}{lll}
\hline Phases & Library & \\
\hline $\begin{array}{l}\text { First } \\
\text { phase }\end{array}$ & $\begin{array}{l}\text { Ancient } \\
\text { library }\end{array}$ & $\begin{array}{l}\text { The most primitive and basic function of the library is as a place to collection } \\
\text { of books. At the same time as an academic and cultural center }\end{array}$ \\
\hline $\begin{array}{l}\text { Second } \\
\text { phase }\end{array}$ & $\begin{array}{l}\text { Early } \\
\text { modern } \\
\text { library }\end{array}$ & $\begin{array}{l}\text { Early modern libraries have the function of two classrooms, and point out the } \\
\text { general educational function of the general knowledge of the library. It also } \\
\text { reveals the functional characteristics of the library that has the potential to } \\
\text { cultivate talents. }\end{array}$ \\
\hline $\begin{array}{l}\text { Third } \\
\text { phase }\end{array}$ & $\begin{array}{l}\text { Modern } \\
\text { library }\end{array}$ & $\begin{array}{l}\text { Modern libraries provide a wealth of information tools and techniques and } \\
\text { skills to solve problems with key sources of information. }\end{array}$ \\
\hline
\end{tabular}

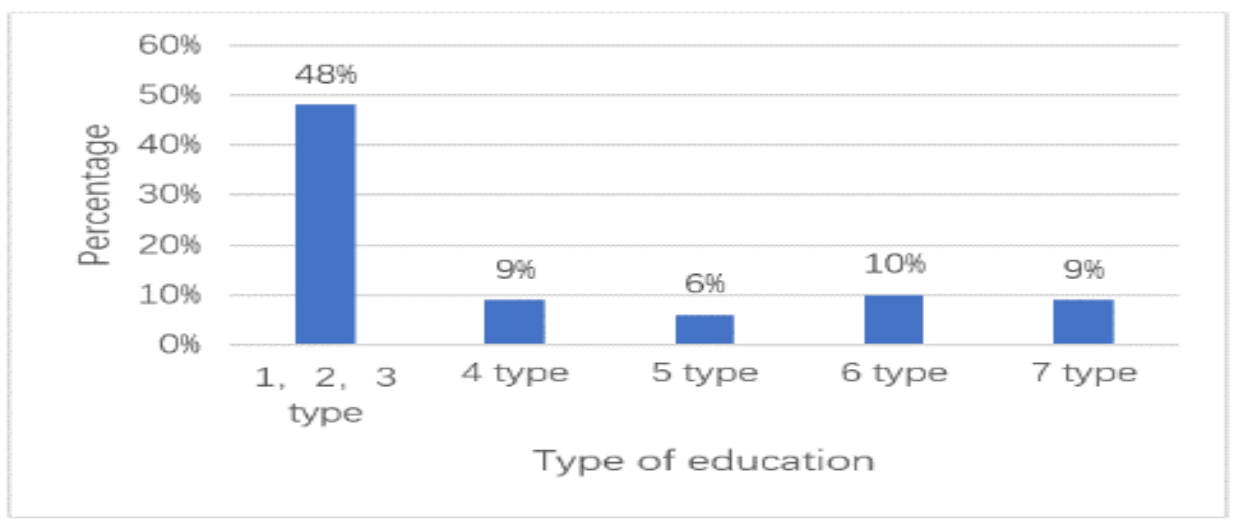

Figure 1. Distribution of education in university libraries at present stage.

As can be seen from the table, types 1, 2 and 3 are the most common forms of education in colleges and universities. In addition, it is found that $68 \%$ of colleges and universities have opened the course of literature retrieval (Schoening \& Wheeler, 2002). At present, the training lectures and information document retrieval are 
mainly based on the training lectures and information document retrieval courses, while other forms of teaching are supplemented.

\section{Analysis on the existing problems and reasons of university library education}

Neglect of library education by the management in colleges and universities. Although the function of education in university libraries has been given full play, there are still some problems in view of the whole. In terms of the current environment of colleges and universities, the basic education of colleges and universities has neglected the educational function of libraries (Feng-Yun, Huan-Ran, \& Ba, 2005).

The main reasons are as follows: 1 . The library is only a service institution in colleges and universities, and the overall support for the education in colleges and universities is insufficient; 2 . College construction is a huge system engineering, and library construction is only a small part of it (Starlin, 2006).

Low enthusiasm of the educators in university libraries. At present, the implementers of the educational function of university libraries are generally librarians in the libraries, most of the libraries do not have fulltime librarians engaged in teaching, and the teaching activities in university libraries are carried out by parttime librarians in some departments. In other words, these librarians are responsible for other tasks such as the libraries besides teaching training (Xue-qin, 2011).

The main reasons are as follows: The teachers in libraries is a few, and the number of full-time librarians is very small. There are very few library teachers who are majored in library, and most of them are teachers who have not received formal training. The treatment is inferior to the treatment of other professional teachers, which leads to the library educators belonging to the weak group at the material and spiritual level in the university education, and it is difficult to draw enough attention with low enthusiasm.

Problems of educational function in the course of library reform. The storage of important documents by virtual library has some shortcomings such as short service life and easy loss. The automatic collection of documents by virtual library lacks certain screening for document collection and non-optimized digital resources have hidden troubles for book education. The teaching space of the virtual digital library generally takes the network as the medium, the allocation of the teacher resources of libraries cannot meet the full-time service of the network teaching, which makes problems existing in the network teaching of libraries hard to be solved in time.

\section{Analysis on Educational Reform Method and Application Effect of University Libraries in Information Age}

In the information age, the improvement of the education quality of university libraries is closely related to the hardware and software construction of libraries themselves. Only the advanced hardware and software support can lay a strong backing for the education activities of university libraries. On the basis of summarizing the present situation and existing problems of university libraries in China, this section gives a brief overview 
of the methods of library reform, and verifies the reform effect of library education by the application of the two-term reform in a university in Zhejiang Province (Jun, 2009).

\section{Perfecting and enriching the construction of collection resources}

The university library is the document information centre, and the modernized university library education needs the sound document resource system. First, traditional paper literature should cover teaching books, extracurricular reading books, scientific research books, world classics, etc. The electronic information document should have access right to each large Chinese database and foreign language database. Secondly, the mode of literature interview should be improved, and the teachers and students should be the main body of literature interview to change the status quo of data collection only by library administrators. Third, the libraries and reference rooms of all departments are established for integrated resource allocation. University libraries can establish a unified resource system with the reference rooms of various schools and departments, check each other's storage and complement each other, and reduce the probability of duplicate book purchase. Fourth, optimize the allocation of resources and reach $75 \%-85 \%$ of teacher and students reading satisfaction rate in the collection configuration, so as to avoid waste.

\section{Improving the ability and comprehensive quality of librarians and educators}

Improve the input of the soft power of library education, strive to strengthen the strength of library management personnel training and selection requirements. Only when the level of comprehensive quality of librarians is raised can the education of libraries be improved.

Specifically, in three aspects: 1 . To provide a good library working environment, to avoid the loss of library talents; 2. With the incentive system of librarians, improve the treatment of librarians, and arouses their enthusiasm; 3 . To perfect the management system of professional books and provide better teaching service for scientific research in colleges and universities.

\section{Optimizing the digital information technology environment of modern university libraries}

Strengthen the construction of the library network hardware, improve the browsing speed of the library network, and configure the library document retrieval classroom to make the library information service develop in the direction of network, digitalization and knowledge. The main measures include perfecting the network technology and equipment of university libraries, improving the network application of university libraries, and establishing the network teaching platform.

\section{Analysis of application effect}

In recent years, a university in Zhejiang Province has attached great importance to library construction and library education. After applying the method of library education reform, the number of visits by teachers and 
students and the amount of web page retrieval have been increased year by year, and the effect of university library education reform has been obvious. Table 2 shows the number of visits to the library.

Table 2

\begin{tabular}{lcccc} 
Library Visit Statistics & & & & \\
\hline Visit type/years & 2014 & 2015 & 2016 & 2017 \\
\hline Number of visitors & $100.2 \mathrm{k}$ & $150.5 \mathrm{k}$ & $270.5 \mathrm{k}$ & $400.3 \mathrm{k}$ \\
Number of online visitors & $50.4 \mathrm{k}$ & $100.8 \mathrm{k}$ & $203.9 \mathrm{k}$ & $433.7 \mathrm{k}$ \\
\hline
\end{tabular}

\section{Conclusion}

This article introduces the function change of library education under the background of digital information technology, makes statistical analysis on the problems existing in university library education in China at the present stage, analyzes the reasons of the problems qualitatively and classifies them, and puts forward the corresponding improvement strategies. Finally, the practical application effect of the education reform of university library is analyzed quantitatively. The main research results of this article are as follows:

(1) Put forward the realization way of library education function in the information age;

(2) Propose the effective strategy of reforming the education of university library;

(3) Have proved the effectiveness of the reform method with practice.

\section{References}

Fahmy, A. F. M. (2014). Systemic reform in chemical education: An international perspective. Journal of Chemical Education, 80(9), 1078-1083. http://dx.doi. org/10.1021/ed080p1078

Feng-Yun, Z., Huan-Ran, T., \& Bao-Shan, K. U. (2005). The practice of education reform of pbl in 8-year medical program in pharmacology. Medical Education.

Gan, Z., Li, Y., Xie, D., Shao, C., Yang, F., \& Shen, Y., et al. (2012). The impact of educational status on the clinical features of major depressive disorder among Chinese women. Journal of Affective Disorders, 136(3), 988-992.

Hou, J., Michaud, C., Li, Z., Dong, Z., Sun, B., \& Zhang, J., et al. (2014). Transformation of the education of health professionals in China: Progress and challenges. Lancet, 384(9945), 819-827. http://dx.doi.org/10.1016/s0140-6736 (14)61307-6

Jun, H. (2009). On the reform of the university library information retrieval education. Journal of Jiangsu Teachers University of Technology.

Korobkov, A. M. (2004). The implementation of educational function of sports federations by means of pedagogical management. Neurobiology of Disease, 17(2), 357-377.

Schoening, J., \& Wheeler, T. (2002). Standards-the key to education reform. Computer, 30(3), 116-117. http://dx.doi. org /10.1109/mc.1997.573680

Starlin, C. M. (2006). The science of education reform. Nature Neuroscience, 9(11), 1345. 
Zhang / Reform Method and Effect Analysis of University Library, Education Based on Digital Information Technology.

Xue-qin, Z. H. A. O. (2011). Discussion on the reform and practice of Freshmen's education of university library [J]. Sci-Tech Information Development \& Economy, 31, 030.

Zhou, L., Liu, T., \& Li, Z. (2011). The research of college student group crisis evolution mechanism and intervention mechanism in higher education zone of china. IEEE, part 2, 1320-1323. http://dx.doi. org/10.1109/icieem.2011.6035398 